\title{
Learning from global suppliers: the diffusion of small wind in low- and middle-income countries
}

\section{Faith H. Wandera*}

Ministry of Energy, P.O. Box 30582-00100, Nairobi, Kenya

Email: fahamala@yahoo.com

*Corresponding author

\section{Margrethe Holm Andersen}

\author{
Department of Politics and Society, \\ Aalborg University, \\ Frederikskaj 10B, 2450 Copenhagen SV, Denmark \\ Email: mhand@dps.aau.dk
}

\section{Rasmus Lema}

Department of Business and Management, Aalborg University, Fibigerstræde 2, P.O. Box 159-9100, Denmark Email: lema@business.aau.dk

\begin{abstract}
An increasing number of low and middle-income countries seek to boost electrification with renewable energy. Yet, most renewable energy equipment and services are imported from global technologies suppliers located in high-income countries. This article aims to learn from global suppliers of small wind turbines: what can we learn about capabilities, opportunities and barriers for diffusion of small wind? What insights can we derive about organisational learning and policy learning to enhance diffusion? Our survey of global producers shows that at firm-level capabilities such as preparation of feasibility reports and selection of project sites are major weakness in developing countries. Limited knowledge of technologies and skilled manpower are also key constraints. While there are opportunities for learning from global suppliers during project planning and installation, low absorptive capacity constrains the further diffusion of knowledge locally.
\end{abstract}

Keywords: capabilities; low- and middle-income countries; diffusion; global suppliers; global value chains; learning from importing; renewable energy; small wind turbines; user-producer interaction.

Reference to this paper should be made as follows: Wandera, F.H., Andersen, M.H. and Lema, R. (2021) 'Learning from global suppliers: the diffusion of small wind in low- and middle-income countries', Int. J. Technological Learning, Innovation and Development, Vol. 13, No. 1, pp.24-49.

Biographical notes: Faith $\mathrm{H}$. Wandera is a Senior Deputy Director of Renewable Energy in the Ministry of Energy, Nairobi, Kenya and a PhD student at the Moi University, Kenya, and Aalborg University, Denmark. She 
holds a Master of Environmental Planning and Management from the Kenyatta University, and has over 32 years of experience in renewable energy policy, implementation and development. Her current research focuses on technological innovation systems, capabilities, and learning in global value chains and how this relates to policy and diffusion of renewable energy technologies.

Margrethe Holm Andersen is a Senior Advisor at the Department of Politics and Society at the Aalborg University and an Academic Coordinator of the AfricaLics Visiting Fellowship Programme. She holds an MA and a PhD from the Aalborg University and has more than 25 years of experience from planning, implementation and evaluation of development cooperation mainly from the Danish Ministry of Foreign Affairs. She is an expert on innovation systems in developing countries and her current research focuses on research capacity development and on learning, innovation and renewable energy pathways.

Rasmus Lema is an Associate Professor at the Aalborg University and a Senior Visiting Associate Professor at the University of Johannesburg, College of Business and Economics. He holds a DPhil in Development Studies from the University of Sussex and conducts research in the intersection between innovation studies and development studies. His current research is focused on policies and practices for technological learning, innovation and competence building in renewable energy sectors in low- and middle-income countries. $\mathrm{He}$ is a member of the board of Globelics and an editor of the Journal Innovation and Development.

\section{Introduction}

An increasing number of low and middle-income countries seek to boost electrification using renewable energy. However, the bulk of renewable energy technologies are produced in high-income countries or in emerging markets with substantial technological capabilities. Green technology manufacturing capacity in most developing country markets is generally limited although in some cases increasing. The role of low and middle-income countries as 'users' in producer-driven global value chains is therefore central to research concerned with increased diffusion of renewable energy technologies. Private firms - which develop, manufacture and distribute technology - are typically located in green economy 'lead markets' and they have an important role in the nature and pace of technology diffusion. Yet there is very little research, which examines their behaviour and views. In particular, their unique insights into the constraints to diffusion in developing country markets is under researched - hence this article aimed at using information from international small wind turbine suppliers to examine firm and country level barriers to diffusion in low and middle-income countries (or 'developing countries'). ${ }^{1}$

We started data collection with the anticipation of being able to gain new insights regarding the diffusion process of renewable energy, with a specific focus on elements and activities in the project cycle of renewable energy projects. In our view, investigations into the practices and perceptions of international suppliers in small wind has the potential to provide important insights into barriers and opportunities for diffusion 
of small wind technologies in different contexts. Such knowledge may help local policy makers and international organisations to establish key points of intervention.

In adopting this global supplier perspective, we draw on global value chain analysis and frame this study with reference to the notion of producer-driven value chains (Gereffi, 1994). However, in this study we turn conventional global value chain analysis on its head: rather than examining the 'learning-from-exporting' hypothesis (Schmitz and Knorringa, 2000), we adopt a 'reverse' value chain analysis to explore learning-from-importing (Haakonsson, 2009) in producer-driven chains (Lema et al., 2018). We focus in this study on learning from global suppliers as opposed to learning from global buyers as is the case in most value-chain research.

The paper focuses on the small wind energy sector and specifically, systems smaller than $100 \mathrm{~kW}$. Small wind is a particularly interesting sector for exploring issues related to learning from importing because this technology exhibits features of 'appropriate technology' and because entry barriers are relatively small compared to, e.g., large wind and solar photovoltaic (PV), and hence there may be greater opportunities for localisation and eventual value chain organisation by domestic firms (Hansen et al., 2018).

The paper is structured as follows: Section 2 introduces key literature related to our triple focus on renewable energy technologies in low and middle-income countries; diffusion of small wind turbine technology and learning from global suppliers. Section 3 presents materials and methods used for the study. In Sections 4 to 7, we present the results from the global suppliers' survey focussing on market expectations; firm and country-level capabilities; organisational learning and policies and barriers and measures for diffusing small wind in developing country markets. Finally, Section 8 presents the conclusions and recommendations arising from the study.

\section{Learning from importing and diffusion of green technologies}

In much of the literature on diffusion of green technologies in low- and middle-income countries, the perspective of technology suppliers has been surprisingly absent. This holds true in general as well as for small wind specifically, although there is only a very small body of literature focussing on this particular sub-sector (Mirza et al., 2009). In this section, we start by laying out the relevance of studying diffusion of renewable energy technology from a global perspective and examine the literature on the diffusion of such technologies in low and middle-income countries. We proceed by explaining why it is important to focus in particular on small wind and what the literature has to say about capabilities, opportunities and barriers for small wind diffusion in low and middleincome countries. Finally, we end this section by focussing on the global technology suppliers' perspective and specify what we expect can be learned from using this perspective.

\subsection{Why study diffusion of renewable energy in low and middle-income countries?}

Our focus on diffusion of renewable energy technologies in low and middle-income countries is motivated by three possible types of benefits from increased use of solar, wind and other renewable energy technologies. First, such technologies can contribute to reducing energy poverty and improving accessibility to energy, not least in rural areas 
(often off-grid) areas (IRENA, 2016; World Bank, 2018). Second, increased diffusion of renewable energy technologies has potential benefits for low and middle-income countries with respect to energy leapfrogging (IPCC, 2014) making it possible to embrace advanced energy technologies developed for and used in industrialised countries (Szabó et al., 2013). Finally, increased use of renewable energy technologies holds the potential of contributing to sustainable industrialisation, as capabilities developed in the planning, implementation and operation of renewable energy projects are also useful in other sectors and contexts (Lema et al., 2015).

The diffusion of renewable energy is particularly relevant for low and middle-income countries because of limited access to grid electrification by majority populations and the tendency for grid electrification to favour wealthier communities. ${ }^{2}$ A more extensive and diversified use of renewable energy resources available in many low and middle-income countries could help ensure greater efficiency in distributed power supply (Avila et al., 2017; IEA, 2020) and addressing existing social inequalities between wealthy and rural communities (Szabó et al., 2013). The grid connection rates reported by many of these countries show a highly uneven distribution of the grid and access to modern energy sources (Avila et al., 2017). One reason for this is that extension of the national grid to remote areas is often not financially viable. In such situations, decentralised electricity generation based on renewable energy sources holds a big potential for improving the access rates through increased off-grid provision of electricity. Poor urban populations may also benefit from small-scale renewable energy systems, however, not least where prices of grid-related electricity are prohibitively high (Wandera, 2020).

In terms of leapfrogging, the global nature of technology development provides a good opportunity to learn from successes and failures in other countries (IPCC, 2014), although there are also many obstacles to successful use of these in new contexts. Lessons for small wind technology are available from, e.g., China and India (Wandera, 2020) and show that both policy interventions and interactive learning have been key in the development of small wind in these countries. In China, for instance, the development of local content laws and provision of support has been instrumental in the successful diffusion of small wind. Further, the development of technical capabilities in the Chinese wind industry highly depended on international technology transfer and the acquisition of external knowledge (Lema et al., 2013). The latter was made possible through partnerships with foreign companies leading to enhanced internal capabilities in Chinese companies (many of which are state-owned). In many developing countries, the acquisition of technology and equipment has been used as a channel for technology transfer and production knowledge flows and hence potentially constitutes a potential precedence for developing local technologies (Evstigneeva, 2016).

Lessons on technology development have in many cases been replicated through learning by doing (Rao and Kishore, 2010), and resulted in increased awareness of the technology promoted. The experience of governments and development agencies in diffusing small scale renewable energy technologies (including small wind) in developing country markets is, however, established by some researchers to still be in its infancy and hence requires enhanced efforts geared towards creating and strengthening of technology markets (Nandakumar et al., 2009). Others have shown that the foundation for current success in market led development of solar PV in East Africa has depended highly on interventions and support by development partners (Ockwell and Byrne, 2015). Key literature in the field, however, stresses that diffusion of renewable energy technologies in low-income countries in particular is both costly and difficult (Rao and Kishore, 2010). 
It depends on the availability of human and financial resources, absorptive capacity in firms and industries, and the available support for enhancing entrepreneurship among other factors (Ockwell and Byrne, 2015).

An additional reason for studying renewable energy technologies and their dissemination in low and middle-income countries relates to their potential to support sustainable industrialisation. Capabilities developed in connection with renewable energy projects may also be useful in other sectors and contexts (Hansen et al., 2018; Lema et al., 2018) - or may help a country move from the position of a being a user of technologies developed elsewhere to actually developing new technologies. Ockwell and Mallett (2013) find that improving the local capabilities to understand and maintain technology through the transfer of technological innovations is useful for economic growth in low and middle-income countries. Developing capabilities could thus be relevant for increased use as well as manufacturing of a broader range of renewable energy technologies including small wind, in the long run.

\subsection{Why focus on small wind?}

Studying diffusion processes is documented to be a complex process that requires an understanding of the technology, the broader environment such as the role of government and other agencies (Bhatia, 1990), and other factors such as education and awareness. There are indications, however, that low and middle-income countries could take advantage of commercial opportunities for renewable energy technologies such as small wind, which has become a conventional or mainstream technology in many high-income countries (Lewis, 2007). Recent literature on small wind in low and middle-income countries has also pointed to the potential for small wind to complement other forms of renewable energy (Hansen et al., 2018; Johannsen et al., 2020).

Small wind could be deployed either as stand-alone or hybrid systems for renewable electricity production, e.g., in off-grid areas. Hybrid systems can be of particular interest in areas where sufficient wind resources are available and where a combination of solar and wind energy may help off-set problems of energy generation emerging from a dependency only on solar (Johannsen et al., 2020). Rather than depending on batteries for storage of electricity produced in the day when the sun is available, a combination of solar and wind energy in a mini-grid may help secure a more stable and sustainable electricity supply. Opportunities to realise this potential, however, are hampered by the failure to carry out proper assessment of wind resources which has in some cases contributed to disappointing levels of energy generation from small wind (Kamp and Vanheule, 2015; Leary et al., 2019). The development of small wind requires site-specific assessments at 10-20 m hubs in resource rich areas but this data is not available for many countries. Government ministries in many low and middle-income countries have made significant progress in collecting wind resource data but most of the available data is more useful to large-scale wind projects compared to small wind. Many actors in low and middle-income countries are also unaware of the potential benefits derived from an increased use of small wind. This lack of awareness affects all levels from policy makers, who lack the capabilities to identify appropriate sites for promoting the technology, to local technology suppliers inadequately versed with site selection, installation and maintenance (Leary et al., 2019) and to local communities. Furthermore, experience from Kenya has demonstrated that the small wind equipment produced by informal 
manufacturers is not up to the required standard and this has contributed to low confidence in small wind technology (Wandera, 2020).

Successful and sustainable importation of wind technology to low and middle-income countries requires semi to highly qualified skills from international markets - or the development of required capabilities in these countries themselves. This requires investments in the development of skills, and support systems (Baker and Sovacool, 2017) that can support new productive capacity and enable optimal operation of the diffused technology. Collaboration with local universities is recommended in the literature as a way of ensuring the availability of technical and policy-making skills (Leary et al., 2019). The need for technical skills at community level is more pertinent for small wind than for solar PV, because of the associated need for higher levels of technical knowledge to operate, maintain and upgrade small wind.

Hence, while there is potential for small wind to complement other renewable energy sources in low and lower-middle income countries there is also a wealth of literature that points to the challenges associated with increased dissemination of small wind. ${ }^{3}$ The immaturity of small wind in low-income countries in particular has been attributed to the numerous challenges associated with the diffusion of renewable energy technologies. There are different ways of categorising the barriers. Mirza et al. (2009) for instance have found that the barriers include policy and regulatory, institutional, fiscal and financial, market-related, technological and information and social barriers, while Khosla et al. (2017) point out that knowledge flows, technology, finance and policies are key elements of technological change.

In the empirical part of this paper, we focus on four sets of barriers for increased dissemination and use of small wind in sustainable energy supplies. The four areas are policy barriers, financial barriers, technical barriers and information barriers, which we consider key to understanding processes of dissemination of small wind. In each of these areas, there are also opportunities for addressing the problems - and measures that can be taken to deal with the barriers.

\subsection{Why focus on global suppliers?}

There are at least three reasons to focus on suppliers in the diffusion process in general and regarding diffusion of small wind in particular. First, suppliers determine the direction of technological development (Are technologies appropriate?), second, they set the prices (Are technologies cheap enough?) and finally, they supply products and services in ways that may be more or less conducive to the diffusion process. In this paper, we focus mainly on the last aspect. We take our point of departure in the wealth of literature on low carbon technology transfer and collaboration showing that 'transfer' of hardware (equipment) often leads to suboptimal outcomes unless accompanied by significant flows of software (knowledge about technologies, such as their installation, operation, maintenance and improvement), for the upgrading of buyers/users on the demand side (Bell, 2012). It is in this respect that the perspective of buyer-supplier interaction is crucially important (Lema et al., 2018).

Many of the global suppliers of small wind have been able to develop their technologies based on demands from a strong domestic market. They have often received public support and worked closely with buyers of the technologies and with knowledge institutions to optimise the functioning of their small wind technology. When such suppliers engage in exporting their specific small wind technologies to other countries, 
new relations between buyers and suppliers are forged. These new relations (partnerships) offer an opportunity for learning, knowledge transmission and cooperation (Khosla et al., 2017), although such opportunities may not always be used to their full potential (Lema et al., 2018). Moreover, the effective diffusion of renewable energy technologies requires close interaction with local actors. Engaging local firms is particularly relevant in low and middle-income countries, where the key actors in the diffusion process often lack both the incentive and capabilities to assume the responsibilities to address identified gaps. Firms and entrepreneurs are identified as key elements in the diffusion process, mainly through their capabilities, skilled man-power and familiarity with technology (Lema et al., 2015). Implementation could be supported by joint ventures, which are established in literature to generate high spill-over effects through transfer of tacit knowledge and improvement of the absorptive capacity of low and middle-income countries for technology imported from high-income countries and, potentially, also for development of localised production of renewable energy technologies. Partners in the development of utility scale wind projects could also assume corporate social responsibility by providing technical and financial support to small wind initiatives, which entails secondment of trained personnel, providing financial support and sharing available data for locations of interest. At the same time, global suppliers from high-income countries supplying renewable energy technologies to low and middle-income countries do so mainly with a view to expand their own business opportunities and not necessarily out of concern for poverty alleviation (Ockwell et al., 2010). This may affect the type and depth of learning that lead partners are willing to engage in.

As implementation of national policies (including energy policies) are often heavily influenced by international agencies, e.g., through funding of renewable energy technology projects (both large and small scale), such organisations can also play a role in ensuring optimal use of the learning spaces that arise or may be created when buyers and suppliers interact in renewable energy projects.

To inform questions about which policies low- and middle-income countries (and their international partners) should pursue in enhancing the dissemination and use of renewable energy technologies in national energy supply, we can now specify, what we need to learn from global buyers. Two questions emerge as critically important: what can we learn from the global suppliers about capabilities, opportunities and barriers for diffusion of small wind? What insights can we derive about organisational learning and policy learning to enhance diffusion?

\section{Survey method}

Primary quantitative and qualitative data for this article was collected using a survey questionnaire using SurveyXact. The questionnaire contained both open and closed questions. Appendix attached to this paper includes further information on the nature of these questions and other aspects of our survey methodology, such as the countries of respondents.

The questionnaire was distributed to 104 small wind companies in Europe, Asia, North America, South America, Australia and Africa. Eighty-seven of the companies were sourced from a small wind suppliers' catalogue (NFRE, 2016) and 32 from an online search. To the best of our knowledge, the survey was distributed to all producers 
of small wind turbines in existence in 2018. Efforts to enhance the response rate were made through phone call reminders, verification of email addresses, and redistributing the questionnaires with request to respond at a new deadline.

We received 50 responses, equal to almost $50 \%$ of the distributed questionnaires, 47 complete and 3 incompletes (see Table 1). It was difficult to establish the status of operation of the 54 companies not responding and 15 companies for which questionnaires could not be delivered. Some companies may no longer exist - and in other cases, respondents declined to participate as they were only dealing in large wind, or was a project organiser, but not a manufacturer of small wind turbines.

Table 1 Survey responses

\begin{tabular}{lccc}
\hline & Distributed & Responses & Response rate \\
\hline Europe & 58 & 28 & $48 \%$ \\
Asia & 26 & 9 & $35 \%$ \\
North America & 12 & 6 & $50 \%$ \\
South America & 3 & 2 & $67 \%$ \\
Australia & 3 & 1 & $33 \%$ \\
Africa & 2 & 1 & $50 \%$ \\
Total & 104 & 47 & $45 \%$ \\
\hline
\end{tabular}

Source: Authors' own data

Some responses needed clarification, which was done via e-mail and/or phone and, in few cases, via face-to-face follow up interviews. The survey results were also complemented with secondary data from international reports and available statistics.

\section{Expectations about small wind markets in developing countries}

Due to the lack of local manufacturers of technologies for electricity production using small wind (and in particular small wind turbines), the interest of global suppliers in exporting to developing country markets is of concern in this study focussing on possibilities for enhanced distribution of renewable energy technology. In our survey, we therefore first asked the respondents how big a share of their sales were from exports and subsequently investigated their experience with export to developing country markets as well as their expectations for future sales in high income and developing country markets respectively.

Based on the survey, $41 \%$ of the firms indicated that exports in the last five years constituted more than $50 \%$ of total sales, indicating that export markets constitute an important part of the foundation for the business of suppliers of small wind turbine technologies. We also asked respondents about their experience with exporting to developing country markets the last five years. India, Afghanistan, Turkey and Belize were the top five countries mentioned as export destinations. The full list of countries reported as export destinations by the respondents is included in Appendix.

We not only asked about exports the last five years, but also about expected evolution of exports to developing countries and high-income country markets the coming five years. Table 2 shows the responses to this question. As seen, most small wind turbine 
manufacturers anticipate an increase in exports to both types of markets, but the expected increase in exports to developing countries is far higher.

Table 2 Expected evolution of exports 2019-2023 - high income and developing country markets

\begin{tabular}{lccc}
\hline & Decrease & No change & Increase \\
\hline High income country markets & $15(35 \%)$ & $10(23 \%)$ & $18(42 \%)$ \\
Developing country markets & $3(7 \%)$ & $13(30 \%)$ & $27(63 \%)$ \\
\hline
\end{tabular}

Source: Authors' own data

The expected decrease in exports to high income country markets was not a key focus of the survey, but may relate to many different factors, including saturation of markets in high income countries; a shift to large scale wind and changes in policies relating to subsidies. For instance, one respondent commented that the market for small wind turbine technologies 'is very unstable because the incentive policy of high-income countries such as feed-in-tariffs may change suddenly. It results that the manufacturer is unable to decide the investing policy (both technical and production). It seems that there is no proper guidance internationally to drive the application of small wind turbine technologies'.

Furthermore, $36(86 \%)$ of 42 survey respondents answering the question believed that developing country markets "could be developed as more important markets if there was more awareness on the benefits and options for small wind technology" (see Table 3). Qualitative statements indicated that this was because "developing countries had more need for electricity, particularly in marginal areas that demanded significant investment in setting up grid power supply infrastructure."

Table 3 The potential of developing country markets

\begin{tabular}{lcc}
\hline & Respondents & Percent \\
\hline Yes & 36 & $85.7 \%$ \\
No & 6 & $14.3 \%$ \\
\hline
\end{tabular}

Notes: $\mathrm{N}=42$. Question: Do you believe that developing country markets could be developed as more important markets, if potential customers were better aware of options for small wind technologies?

Source: Authors' own data

To summarise, the survey shows that many of the global suppliers of small wind turbine technologies are interested in exporting their technology and expect an increase in their export to developing country markets in coming years. This is, potentially, a promising point of departure for enhancing the diffusion of small wind technologies in these countries. In other words: it is a necessary, but not sufficient condition for successful dissemination of the technologies available.

\section{Country and firm-level capabilities for small wind adoption and use}

Literature has shown that capabilities are key to the long-term viability of renewable energy technologies (Bell, 2012; Byrne et al., 2012). Distinguishing between developing country markets and high-income country markets, we therefore asked the survey 
respondents to rate country-level conditions for small wind adoption in the markets (countries) to which they export.

\subsection{Country-level conditions}

Figure 1 aims at illustrating the rating of country-level conditions cf. responses received in high-income countries and developing country markets respectively. The figure is essentially a 'spider diagram' based on the numerical information available in Table A2 in Appendix. Respondents were asked to rate country level conditions using five different parameters:

1 availability of financial support for small wind technology

2 availability of supporting firms (e.g., for installation or operation and maintenance

3 availability of lean procedures for importing to the country

4 availability of skilled manpower for small wind

5 knowledge of small wind technology.

Average ratings for each category were calculated and inserted in the spider diagram for high-income and low-income country markets respectively.

Figure 1 Assessment of the conditions for small wind technology adoption in the markets to which suppliers export

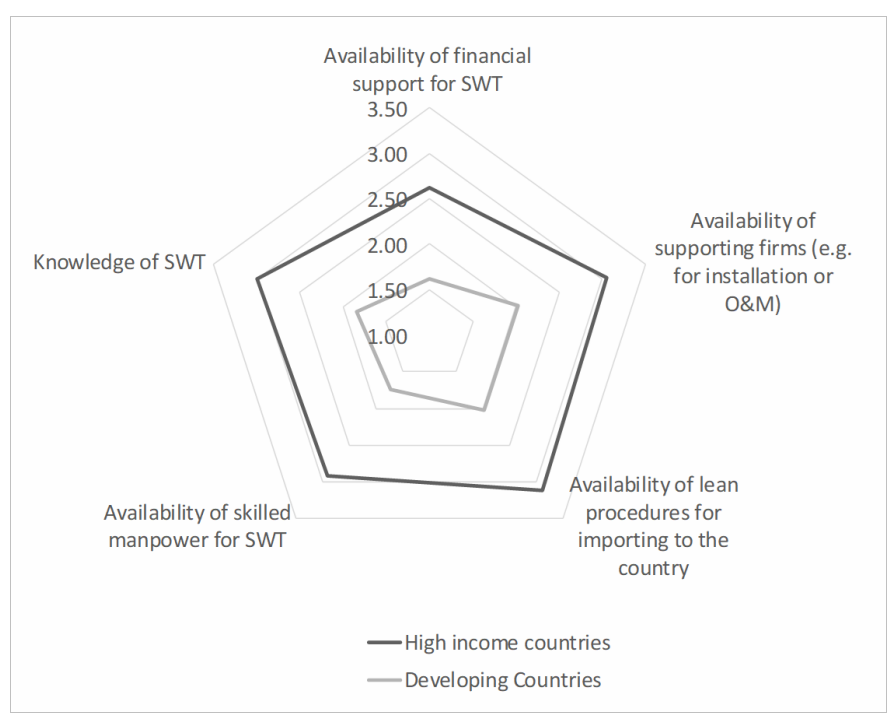

Notes: Respondents were asked to assess the country conditions keeping in mind the most important countries to which they had sold small wind technology the last five years. The assessment used a Likert scale ranging from basic (1) to advanced (5) and the figure shows average of high income and developing countries respectively.

Source: Authors' own data 
As seen in Figure 1, respondents indicated a lower average rating of country-level capabilities in developing country markets (light grey, inner 'circle') compared to high-income markets (dark grey, outer 'circle'). Differences between the two types of markets is strongest as far as availability of finance and the 'leanness' of import procedures into the technology-using country is concerned. The difference in rating between low-income country markets and high-income countries is lowest in the availability of support from the government.

\subsection{Firm level conditions (users)}

Figure 2 also uses a spider diagram to present results from the rating of firm-level capabilities in high-income (dark grey) and developing countries markets (light grey) respectively. Firm-level capabilities in high-income countries are rated higher (i.e., seen as more advanced) compared to firm level capabilities in low and middle-income countries on all seven parameters used. These parameters are:

1 handling of import procedures for small wind technologies

2 selecting project sites

3 preparing feasibility reports

4 knowledge regarding financing

5 technical skills

6 knowledge of small wind technologies

7 project management.

Figure 2 shows that firms in low and middle-income countries rate higher on technical skills and handling of import procedures for small wind technologies compared with all other capabilities assessed. Firms in high-income countries rate higher on technical skills, project management and knowledge of small wind technologies. Selecting project sites, preparing feasibility reports and handling of import procedures are rated slightly lower, but still perceived to be stronger among firms in high-income countries than among firms in developing country markets. The lowest rated capability for firms in high income countries is preparing feasibility reports.

Qualitative responses to the survey attributed the observed pattern for firm and country-level capabilities of developing country markets to "low knowledge levels in low-income countries." Other reasons mentioned were "difficulties in expanding small wind technology companies, which are small and generally unable to develop efficient solutions and generate sufficient revenues to sustain the small wind technology businesses from sales of individual units" and "limited access to financing from banks due to lack of collateral." High-income markets on the other hand were reported to "have large wind companies with strong ability to grow organically since their profits relied more on services rather than sale of individual units." 
Figure 2 Rating of capabilities in importing firms

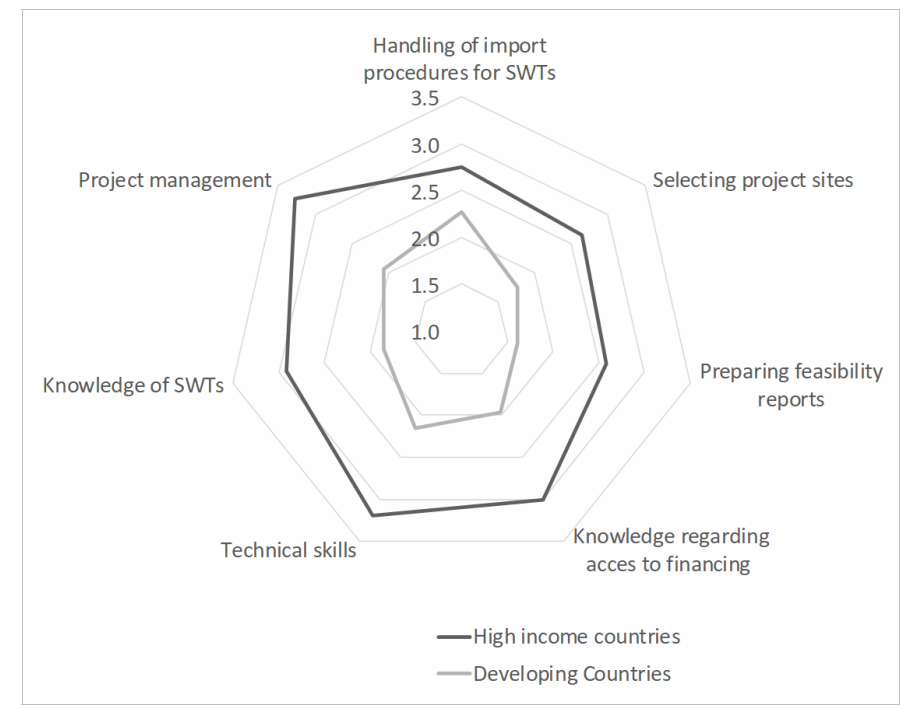

Source: Authors' own data

The survey respondents further cited various constraints encountered in diffusing small wind technology in developing country markets. The following constraints were noted: "high risk of small wind business, which is still immature in low-income countries, to the extent that it is not easy to accurately define the long-run benefits"; "problems in identifying ideal sites for small wind technologies, which highly depends on the wind resource availability"; "high operation and maintenance costs of small wind technology, which makes it uncompetitive with solar PV, whose logistics and ubiquity made it a more favoured option"; and "poor reliability records of small wind technologies in developing country markets (depending on the make)." One respondent, however, observed that "very small and reliable wind chargers $(10-50 \mathrm{~kW})$ of good designs are available in some countries." This response links well with the high prevalence rates of technological capabilities on small wind in some developing country markets such as, e.g., India and China.

\section{Insights on organisational learning and policy}

As described earlier, the survey respondents perceived firm- and country-level capabilities in developing country markets (all low-income and middle-income countries) to be lower than capabilities in high-income country markets along the specified dimensions at the firm-level (see Figure 2). This implies a perceived marked gap in small wind capabilities between these two groups of countries - in spite of the fact that some countries falling in the category of developing country markets (notably India and China) have developed considerable technological capabilities. The general disparity in capabilities between high-income and low-income countries in particular is supported by literature (Archibugi and Coco, 2004; Bell and Pavitt, 1993). The existence of such a gap calls for the key question on how the gap could be bridged for the benefit of both 
developing country markets and high-income countries with respect to increased use of small wind technologies.

In this section, we therefore discuss some insights on organisational learning and policy originating from the survey of global suppliers in small wind and how these insights might help importing countries and organisations learn from global suppliers to enhance the diffusion process.

\subsection{Support and interactive learning}

As noted in the literature review, learning and knowledge acquisition constitute an important possible way of bridging capability gaps and countries like India and China have used different methods to develop their capabilities in the field. A key opportunity identified for raising capacity of importing firms, is the support from international small wind companies to buyers of small wind in low and middle-income countries. To shed light on this dimension we asked survey respondents "What do you provide to your buyers apart from the opportunity to buy your products?"

The survey respondents indicated, in order of importance, engaging in: "the provision of knowledge on small wind products; access to financing options; conducting feasibility studies; joint project solving and technical assistance on installation, and access to operation and maintenance" (Figure 3). Less used forms of support indicated by survey respondents such as local manufacturing, license production, turn-key offer, information on use cases, hybrid solutions and systems design were also mentioned. Survey respondents cautioned that the cost of all additional support was borne by the buyers.

Figure 3 Support to buyers in low-income countries

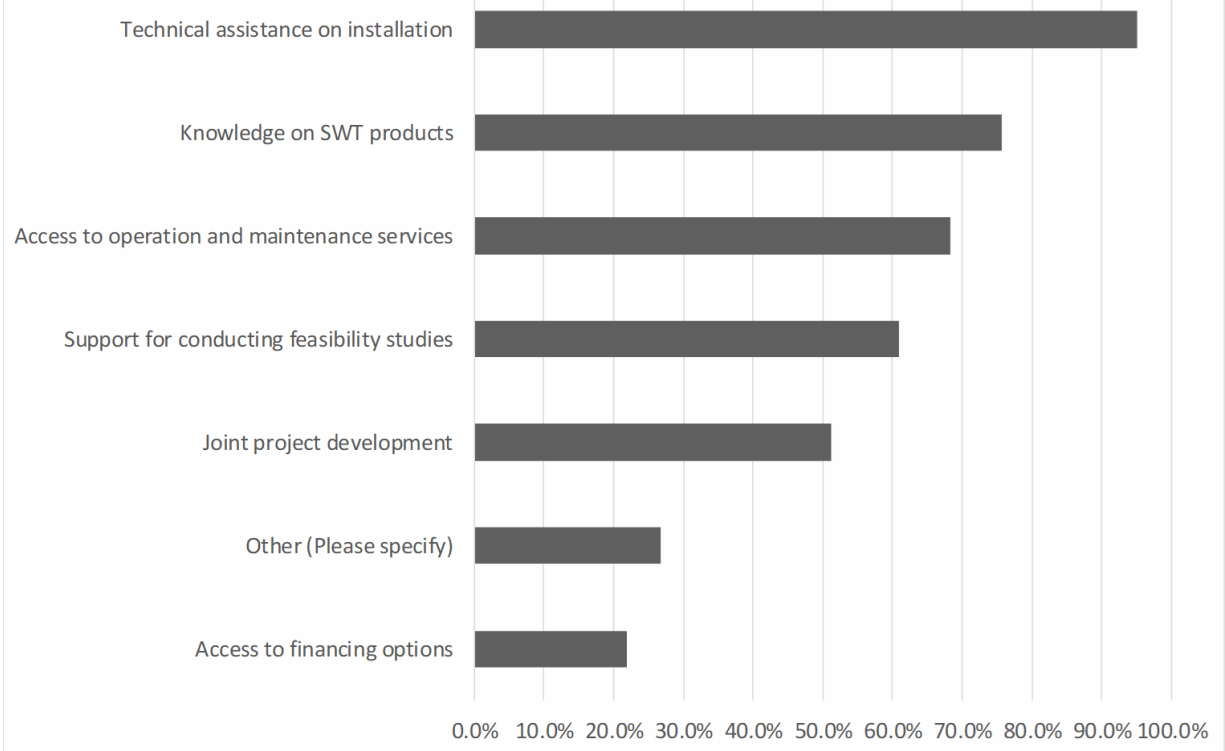

Notes: $N=45$. Survey questions: What do you provide to your buyers apart from the opportunity to buy your products?

Source: Authors' own data 
The survey respondents indicated availability of opportunity for engaging in joint project development in developing country markets to "serve communities with limited access to the grid who had more need for electricity at home, on-farm, and in small industries" (reported by 23 of 45 respondents, equal to 51\%). This is possible through "experimenting with solar PV/wind hybrids in areas where solar and wind resources are abundant thereby facilitating the attainment of a critical mass of innovators and accelerating uptake of small wind." Such partnerships were indicated by survey respondents to have the potential to "raise company profiles in international markets through the learning experience imparted to low-income countries."

To address the same issue from a different angle, we asked not only about support (one way learning flows) but also about interactive learning activities. We asked "How frequently do you engage in the below activities during joint project development with your buyers?" and respondents were required to indicate the share of projects during the last five years in which such interactive learning activities had occurred. The top interactive learning activity was user-producer interaction in the installation phase (see Figure 4). 66\% of respondents indicated that involvement of buyers in installation occurred in half or more of their developing country projects (or instances of sale) the last five years. Critically, this involved training of staff in buyer firms.

Figure 4 Interactive learning activities in small wind technology buyer-supplier relationships

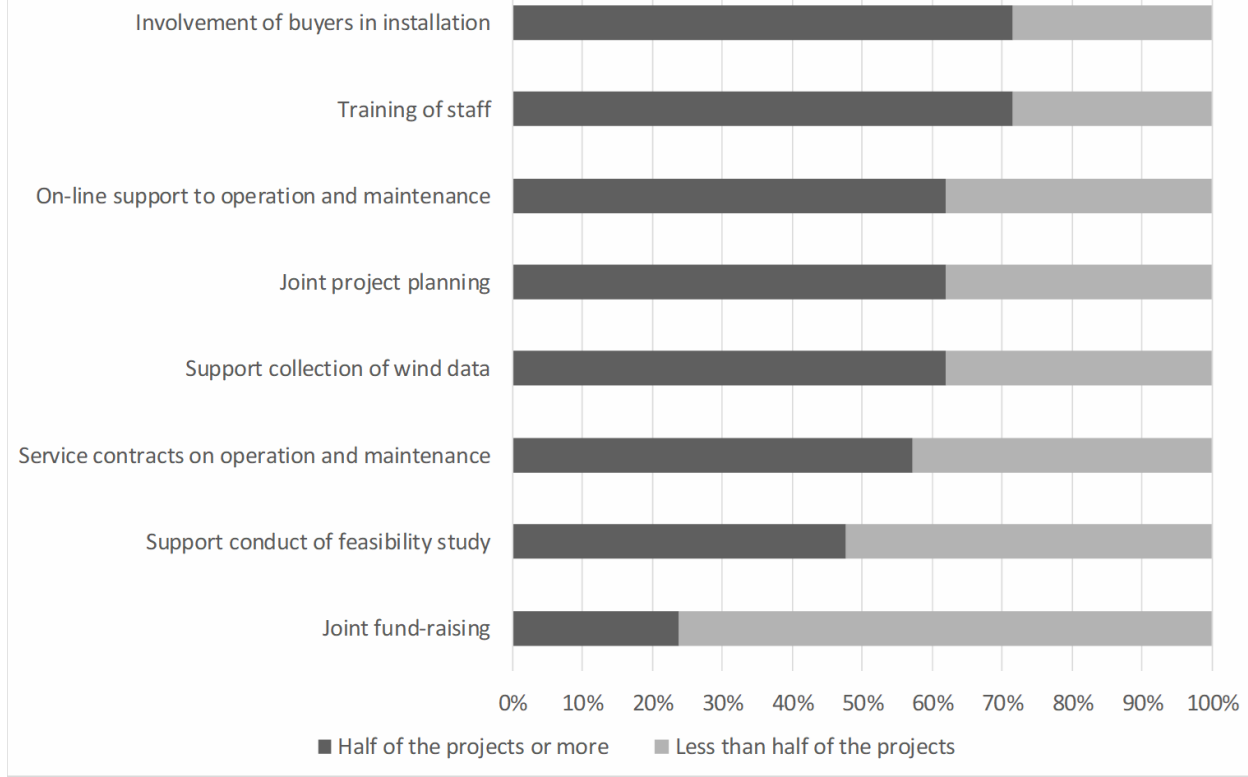

Notes: Question: How frequently do you engage in the below activities during joint project development with your buyers? Please indicate share of projects during the last five years.

Source: Authors' own data 


\subsection{The role of partnerships}

The findings above are relevant because partnerships between buyers and suppliers have been known to generate high spill-over effects of tacit knowledge and could support the development of local content (Hansen et al., 2016) necessary for diffusing small wind technology. High-income countries could benefit from this arrangement through increased exports to developing country markets resulting in a boost in sales and return on investment, while low- and middle-income countries (and low-income countries in particular) could benefit from development of enhanced capabilities in small wind with potential spill over to other renewable energy technologies and sustainable industrialisation more generally. Ensuring the success of such partnerships depends on the efforts exercised by governments in low- and middle-income countries to strengthen linkages with international agencies and markets thereby bringing about the needed technological change. Improving the enabling environment in low- and middle-income countries is crucial, particularly the development of favourable policies and the provision of government financing for implementing projects.

We observe that the common forms of support from international technology suppliers to buyers in developing country markets closely relate to the firm- and country-level capabilities assessed in Subsection 5.1 and 5.2, particularly with respect to knowledge on small wind technology products; access to financing options; conducting feasibility studies; joint project solving; technical assistance on installation; and access to operation and maintenance. These specific capabilities were observed to be weak in developing country markets, but stronger in high-income country markets. This implies that the support offered by small wind manufacturers to buyers in developing country markets already targets key capability areas at firm- and country-level that require to be developed. It could pay off for high-income countries to further strengthen the support already offered in these specific areas through joint project development with small wind technology firms in developing country markets. This is important for developing firm capabilities in these countries, particularly with respect to selecting project sites, preparing feasibility studies, handling of import procedures, project management and knowledge regarding access to financing - areas in which firm capabilities were identified to be weak. At the country-level, developing country markets could benefit through enhanced capabilities with respect to financial support, government feed-in-tariffs/subsidies and lean import procedures as these were identified to be the weakest. Capabilities relating to skilled manpower and support to firms' operation and maintenance activities also need to be developed as they were established to be lower in developing country markets than in high-income countries. Finally, developing country markets also need to enhance their capability to conduct site specific assessments which the literature indicates to be a weakness resulting in low energy generation and hence limited reliability of small wind systems (Johannsen et al., 2020).

\section{Barriers to and measures for small wind diffusion}

In this section, we summarise and discuss barriers to diffusing small wind identified from qualitative data and collected from global suppliers of small wind responding to the survey. Barriers were classified into policy, financial, technical, and information and communication barriers (Mirza et al., 2009). For each type of barrier, we also discuss a 
range of measures, which according to the respondents could enhance the diffusion of small wind in low and middle-income countries.

\subsection{Policy barriers and measures to remove these}

Policy barriers are important to identify as removing them may help enhance possibilities for dissemination of small wind technologies in developing country markets. Global suppliers identified various policy barriers such as the "predominantly heavier government support for large wind turbines and solar PV systems in several countries, which contributes to insufficiently developed markets for small wind technology; uncertainty regarding power prices and payment for the power produced; insistence on power purchase agreements which take time to negotiate for both stand alone and grid connected systems and inadequate legislation and infrastructure." Another policy barrier cited by the survey respondents was the "inadequate balance between the investment and effort required to establish a conducive market size for generating significant revenue, which makes small wind business less interesting."

Respondents suggested "improving the local policy for renewable energy, particularly feed-in-tariffs, enhanced government support and political will for off-grid electrification." Implementing projects as part of corporate social responsibility was suggested for both local and foreign companies. "Mandatory local involvement in installation and maintenance through partnership with skilled foreign firms" was suggested as a means of strengthening local capabilities for micro and mega projects particularly in communities that still rely on diesel generators which are costly and a source of environmental pollution.

As mentioned earlier, there was optimism surrounding the perceived potential of developing country markets as export destinations. However, this optimism was dampened by the observation that technology diffusion in these markets "depended on the ability of low-income country governments to establish a transparent framework or certification requirements." The unavailability of such a framework was seen to "present barriers to entry with a defined strategy, particularly since the small wind technology markets in these countries are not well developed."

\subsection{Financial barriers and mitigation measures}

As noted by, e.g., Gillingham and Sweeney (2012), the diffusion of small wind is also affected by the high initial capital costs affecting the retail price of grid electricity and implying that energy generation using small wind has often required financial subsidies to attain economic efficiency.

Hence, financial barriers can limit the possibilities to invest in new technologies and the global suppliers participating in the survey also noted a range of financial barriers to small wind diffusion. These included "limited access to channels for raising and transferring funds by potential buyers in low-income countries which limited their ability to close deals (e.g., Pakistan, Argentina, Belize and a few other countries); and insufficient government support and budgets for small wind investments, which led to a scramble for cheap solar and small wind technology products from Asian markets, thereby obstructing entry of suppliers with better quality products." Most projects in developing country markets were reported to "rely on foreign grants for which conducting feasibility studies was mandatory." This was considered 'a bump on the way' 
to enhancing electrification in these countries, which had a genuine need but limited support. The overheads associated with small wind investments were identified to "contribute to inadequate returns even for feasible projects."

Global suppliers of small wind further indicated that "interaction between local small wind technology companies and international agencies through bilateral arrangements" offered opportunity to achieve the Sustainable Development Goals. In addition, respondents suggested increased "access to adventurous financing from local and national governments by local small wind companies to facilitate setting up demonstration projects that generate information on the reliability of technology for community use." These suggested measures were indicated to be "essential for developing local capabilities in design, manufacturing, O\&M and promoting strong distributor networks."

Low and middle-income countries that have challenges in accessing financing to support the diffusion of low carbon technology often resort to technology options that are not necessarily advanced but meet the affordability criteria. Such has been the case with the diffusion of solar PV products in the African continent which has been motivated by the ease of packaging into micro units that are portable and easy to install, and affordable to communities who are not able to access grid electricity (Leary et al., 2019; Moner-Girona et al., 2019). It has been established, however, that locally manufactured SWT can guarantee more energy and lower levelised cost of energy if the unit is correctly placed (Leary et al., 2019).

\subsection{Technological barriers and mitigating measures}

As discussed in Section 2, technological capabilities are key for diffusion of renewable energy technologies in general as well as for small wind. Global suppliers in the survey identified the following technological barriers: "the unavailability of technical skills for installation compelled the use of cranes or else down-sizing small wind technology units hence compromising on energy delivery; inadequate site-specific assessment before installation; and the absence of local manufacturing of small wind in low-income countries, which limits the extent to which available designs could be replicated."

Survey respondents also suggested the "enhancement of the skills of local companies through support from small wind technology manufacturers, technical training and service programs." This could be achieved through "employer investment in developing specific capabilities of employees, strong back-up from parent companies, and close collaboration and partnerships between manufacturers, actors and local business firms in low-income markets." This was seen by the global suppliers to be important for "improving available designs to produce new generations of turbines that address pricing, lowering investment, operation and maintenance costs." Potentially, this could enable small wind to compete with solar PV whose manufacturing costs have gone down considerably. "Integration of small wind technology with solar PV as hybrids for powering communities through isolated grids, particularly where wind speeds and solar resources permitted" was recommended by some survey respondents, in addition to optimising systems to match delivery according to the needs of users.

\subsection{Information and communication}

Some of the global suppliers responding to the survey also commented on information and communication barriers that might act as a barrier for market development and 
enhanced dissemination of small wind technology. They quoted "limited awareness on wind and solar PV hybrids; limited internet connectivity in some countries; limited learning from the first project which made it expensive or infeasible to replicate projects; limited number of agents providing information on low-income markets which constrained the decision of foreign small wind technology companies to venture into these markets; inadequate reliable linkages with the distributor network." Respondents described the setting up of distributor networks to be 'demanding on time and effort'. This was reported to lead to "loss of guarantee of trust in specific products which are patented thereby restricting market entry and growth." Potential partners in developing country markets were indicated to have "limited knowledge on the advantages of small wind technology in the most appropriate sites when evaluated on technology versus technology basis." Joint ventures were thus suggested as an appropriate strategy for enhancing learning between small wind turbine manufacturers and buyers.

According to one respondent from China, five specific considerations are made before venturing into new markets. They include: "the availability of local know-how with respect to competency; knowledge levels by the local partner regarding building and environmental permits and local legislation; the prevailing electricity prices and options for sale of electricity; the financing options available, including interest rates and guarantee of cash flow; and the gut feeling about the market with respect to corruption and instability in the country."

Provision of information "on reliable distribution agents, potential customers and the local wind resource availability", was suggested as a means of "minimising the time and effort spent by small wind technology manufacturers on market development."

\section{Summary and conclusions}

An increasing number of low and lower middle-income countries seek to boost electrification with renewable energy. This article ultimately aims to support this process by seeking insights from global suppliers in the small wind sector on opportunities for expanding the use of small wind turbine technologies in developing country markets. It was motivated by the belief that small wind can play an important role in electrification in particular in decentralised hybrid systems in areas with appropriate wind conditions.

In this section, we return to our two overall research questions: What can we learn from global suppliers about capabilities, opportunities and barriers for diffusion of small wind? What insights can we derive about organisational learning and policy learning to enhance diffusion? The latter also includes a response to questions related to what measures could be used to enhance the diffusion of small wind and improve user-capabilities (technological learning) as well as capabilities of policy makers and practitioners (policy learning).

First, it should be emphasised that global suppliers expected exports to both high-income country markets and developing country markets to increase in the coming five years - but the majority of global small wind technology suppliers expected a more significant growth in exports to developing country markets.

While it may be a positive sign that lead-firms expect markets for small wind in developing country markets to grow in the immediate future, this did not, however, reflect a positive assessment of the firm and country-level capabilities in these countries. On the contrary, global suppliers generally found that firm and country-level capabilities 
were less well developed in these countries, reflecting that they are mainly 'users' in producer-driven global value chains and often do not have the capabilities in place to adopt the small wind technologies available and used in high-income countries. The lack of firm and country capabilities hampers diffusion of small wind in itself as well as the possible 'co-benefits' that may be obtained from a more extensive use of renewable energies aimed at supplying sustainable energy for all.

The international manufacturers' perception of low-income countries as 'potential export destinations' implies the possibility of partnerships and joint implementation of projects. This interest in developing country markets may relate to policy changes and saturation of markets in high-income country markets leading to a desire among global suppliers to expand their markets. At the same time, the need to expand decentralised electricity generation could justify partnerships focussed on developing small wind seen from the point of view of low and middle-income countries if other factors (e.g., sufficient wind resources) are also in place.

Our main substantive conclusions fall in two groups. The first regards what we can learn from global suppliers about the country-level conditions and firm-level capabilities of importers. We sought to investigate the conditions and capabilities because these are widely agreed to be fundamental prerequisites to diffusion and because, despite this agreement, there were no existing studies seeking to examine these conditions and capabilities in the small wind sector. We do establish that there are differences in firm and country-level capabilities between developing country markets and high-income country markets and the disparity in capabilities between these two categories of countries is present at both firm and country-level. The identification of these gaps is unsurprising in itself, but our survey proved useful as a means to identify the specific dimension where this disparity in capabilities are starkest and where international support and partnerships could potentially serve to bridge the identified gap. For example, we find that capabilities, which are technological in nature (e.g., project management and technical skills) constitute a significant gap which is larger than capabilities that are more business-focused (e.g., handling of import procedures and knowledge regarding access to financing). The areas where capabilities were rated lowest in developing country markets in absolute terms were preparation of feasibility reports and selection of project sites. Regarding country level conditions, the biggest gap between the two categories of countries was found in knowledge about small wind technology and the areas where conditions were rated most unfavourable were local availability of financial support and local availability of skilled manpower equipped to engage in small wind technology diffusion. The identification of these domains provide important pointers to international organisations seeking to enhance the diffusion of appropriate renewable energy technology.

The second group of conclusions regard what firms and policy makers in importing destinations can learn from global suppliers in terms of organisational learning and policy learning. Crucially, the domains which global suppliers bring to the table in developing country markets (according to their self-reporting) are technological in nature, including technical assistance of small wind installation, knowledge on small wind products and operation and maintenance capabilities as the most frequently identified ones. The conduits for knowledge transfer (or 'learning mechanisms') in these domains span learning-by-doing in the phases of project planning and installation where buyers indicated that engagement with importers occurred and active knowledge transfer in activities devised to train staff in technology-using organisations. These findings raise 
question about what happens to the knowledge, which is transferred during such joint activities. The danger is that limited absorptive capacity and institutional base conditions means that knowledge is not diffused locally to support further diffusion, but this should be examined in further research. The findings also show that the activity that was identified as, by far, the most infrequent collective activity was joint fundraising. Hence, there may be a need to support collective proposal development.

Concerted efforts by leaders in low and middle-income countries is necessary for making use of insights such as those presented in this article and for generating the required technological change. This process also entails strengthening linkages with international agencies with a view to facilitating the flow of knowledge, identification of solutions and efficient allocation of available and new resources.

Our findings may help design initiatives aimed at overcoming constraints and enhancing the extent to which demonstrations can be used for creating further awareness. The lack of supply base and requisite technical skills presents challenges in installation of small wind systems while the absence of local manufacturing constrains the replication of available designs. These could be enhanced with programs to facilitate user-producer interaction. In addition, local policy could beyond enhancing the diffusion of small wind in general, emphasise mandatory local involvement in project implementation as well as O\&M. There is a need to foster relationships with bilateral partners to increase access to financing, development of local technical capacity to improve available designs, which could result in improved affordability, promotion of solar PV/small wind hybrids, and improved access to information on distributor agents, potential customers and resource availability.

This study adopts a supply perspective which can be criticised (rightfully) for side-lining the role of the adopter in the technology diffusion process (Byrne et al., 2012). Yet, the approach adopted here was precisely to learn from the global supply base with the aim of strengthening users of small wind technologies. That said, future studies could integrate the demand and supply perspectives to the diffusion of small wind for comparison.

This study also investigated 'developing country markets' using a very broad definition (i.e., encompassing both low, lower-middle and higher-middle income countries, which does not do justice to the very big differences between countries in these different categories. This may restrict the usefulness of the study in terms of facilitating a clear understanding of how the capabilities for diffusing small wind differ between specific countries. We therefore recommend further investigation of differences in capabilities, opportunities and barriers between individual countries where small wind is viable as a way of further refining an understanding of the dynamics at play and the possible implications for policy and practice.

In terms of policy, we have identified the need for governments to exercise the political will to overcome identified barriers to small wind diffusion. This could be through allocation of adequate financing for small wind projects; improving clarity on payment for power produced; developing markets to attract investors; enhanced access to external financing and support for conducting feasibility studies; developing the technical skills of local personnel for installation and O\&M; promoting awareness on solar PV hybrids and developing the distributor network and improved access to internet. These needs are closely related to the measures suggested by the survey respondents particularly with respect to improving the policy environment, increased access to financing, promoting the establishment of distributor networks, developing technical skills, 
integration of solar PV with small wind and enhanced availability of information. This implies that governments in low- and middle-income countries - and in particular in lowincome countries - need a structured approach to address needs and capitalise on the opportunities identified.

\section{Funding}

Research on which this article is based was part of a research project entitled Innovation and Renewable Electrification in Kenya (IREK) and was supported by the Danish Ministry of Foreign Affairs Grant DFC 14-09AAU.

\section{Acknowledgments}

We are grateful for the support offered for data collection by Rasmus Magni Johannsen, former intern at African Centre for Technology Studies (ACTS) and the IREK Project. Contributions offered by Dr. Rebecca Hanlin (ACTS), and Professor Michael Korir (School of Business Management, Moi University, Eldoret, Kenya) to improve the article are also greatly appreciated. This study is part of a broader investigation of dissemination of small wind in Kenya in an upcoming PhD dissertation (Wandera, 2021).

\section{References}

Archibugi, D. and Coco, A. (2004) 'A new indicator of technological capabilities for developed and developing countries (ArCo)', World Development, Vol. 32 [online] https://doi.org/10.1016/ j.worlddev.2003.10.008.

Avila, N., Carvallo, J.P., Shaw, B. and Kammen, D.M. (2017) 'The energy challenge in Sub-Saharan Africa: a guide for advocates and policy makers part 1: generating energy for sustainable and equitable development', Oxfam Research Backgrounder [online] https://www.oxfamamerica.org/static/media/files/oxfam-RAEL-energySSA-pt1.pdf.

Baker, L. and Sovacool, B.K. (2017) 'The political economy of technological capabilities and global production networks in South Africa's wind and solar photovoltaic (PV) industries', Political Geography, Vol. 60 [online] https://doi.org/10.1016/j.polgeo.2017.03.003.

Bell, M. (2012) 'International technology transfer, innovation capabilities and sustainable directions of development', in Low-Carbon Technology Transfer. From Rhetoric to Reality, Routledge, London [online] https://doi.org/10.4324/9780203121481.

Bell, M. and Pavitt, K. (1993) 'Technological accumulation and industrial growth: contrasts between developed and developing countries', Industrial and Corporate Change, Vol. 2, pp.157-210 [online] https://doi.org/10.1093/icc/2.2.157.

Bhatia, R. (1990) 'Diffusion of renewable energy technologies in developing countries: a case study of biogas engines in India', World Development, Vol. 18 [online] https://doi.org/ 10.1016/0305-750X(90)90073-7.

Byrne, R., Smith, A., Watson, J. and Ockwell, D. (2012) 'Energy pathways in low-carbon development: the need to go beyond technology transfer', in Ockwell, D.G. and Mallett, A. (Eds.): Low-Carbon Technology Transfer: From Rhetoric to Reality, pp.23-42, Routledge, London. 
Evstigneeva, L. (2016) 'International technology transfer impact on developing countries: the case of Russia and China', Humanities and Social Sciences Review, Vol. 4, pp.505-515.

Gereffi, G. (1994) 'The organization of buyer-driven global commodity chains: how U.S. retailers shape overseas production networks', Commodity Chains and Global Capitalism, pp.95-122 [online] https://doi.org/10.1177/0730888405277964.

Gillingham, K. and Sweeney, J. (2012) 'Barriers to implementing low-carbon technologies', Climate Change Economics, Vol. 3 [online] https://doi.org/10.1142/S2010007812500194.

Haakonsson, S.J. (2009) 'Learning by importing' in global value chains: upgrading and South-South strategies in the Ugandan pharmaceutical industry', Development Southern Africa, Vol. 26, pp.499-516 [online] https://doi.org/10.1080/03768350903086861.

Hansen, M., Buur, L., Kjær, A.M. and Therkildsen, O. (2016) 'The economics and politics of local content in African extractives: lessons from Tanzania, Uganda and Mozambique', Forum for Development Studies, Vol. 43, pp.201-228. [online] https://doi.org/10.1080/08039410.2015. 1089319.

Hansen, U., Gregersen, C., Lema, R., Samoita, D. and Wandera, F. (2018) 'Technological shape and size: a disaggregated perspective on sectoral innovation systems in renewable electrification pathways', Energy Research \& Social Science, Vol. 42, pp.13-22 [online] https://doi.org/10.1016/j.erss.2018.02.012.

International Energy Agency (IEA) (2020) Africa Energy Outlook, International Energy Agency, Paris.

IPCC (2014) 'International Technology diffusion', in Climate Change 2013 - The Physical Science Basis. Cambridge University Press, Cambridge [online] https://doi.org/10.1017/ CBO9781107415324.004.

IRENA (2016) Renewable Energy and Jobs: Annual Review 2016 [online] https://www. seforall.org/sites/default/files/IRENA_RE_Jobs_Annual_Review_2016.pdf (accessed 30 August 2020).

Johannsen, R.M., Østergaard, P.A. and Hanlin, R. (2020) 'Hybrid photovoltaic and wind mini-grids in Kenya: techno-economic assessment and barriers to diffusion', Energy for Sustainable Development, Vol. 54 [online] https://doi.org/10.1016/j.esd.2019.11.002.

Kamp, L.M. and Vanheule, L.F.I. (2015) 'Review of the small wind turbine sector in Kenya: status and bottlenecks for growth', Renewable and Sustainable Energy Reviews, Vol. 49, pp.470-480 [online] https://doi.org/10.1016/j.rser.2015.04.082.

Khosla, R., Sagar, A. and Mathur, A. (2017) 'Deploying low-carbon technologies in developing countries: a view from India's buildings sector', Environmental Policy and Governance, Vol. 27 [online] https://doi.org/10.1002/eet.1750.

Leary, J., Schaube, P. and Clementi, L. (2019) 'Rural electrification with household wind systems in remote high wind regions', Energy for Sustainable Development, Vol. 52, pp.154-175 [online] https://doi.org/10.1016/j.esd.2019.07.008.

Lema, R., Berger, A. and Schmitz, H. (2013) 'China's impact on the global wind power industry', Journal of Current Chinese Affairs, Vol. 42, pp.37-69 [online] https://doi.org/10.1177/ 186810261304200103.

Lema, R., Hanlin, R., Hansen, U. and Nzila, C. (2018) 'Renewable electrification and local capability formation: linkages and interactive learning', Energy Policy, Vol. 117, pp.326-339 [online] https://doi.org/10.1016/j.enpol.2018.02.011.

Lema, R., Iizuka, M. and Walz, R. (2015) 'Introduction to low-carbon innovation and development: insights and future challenges for research', Innovation and Development, Vol. 5, pp.173-187 [online] https://doi.org/10.1080/2157930X.2015.1065096.

Lewis, J.I. (2007) 'Technology acquisition and innovation in the developing world: wind turbine development in China and India', Studies in Comparative International Development, Vol. 42 [online] https://doi.org/10.1007/s12116-007-9012-6. 
Mirza, U.K., Ahmad, N., Harijan, K. and Majeed, T. (2009) 'Identifying and addressing barriers to renewable energy development in Pakistan', Renewable and Sustainable Energy Reviews, Vol. 13 [online] https://doi.org/10.1016/j.rser.2007.11.006.

Moner-Girona, M., Bódis, K., Morrissey, J., Kougias, I., Hankins, M., Huld, T. and Szabó, S. (2019) 'Decentralised rural electrification in Kenya: speeding up universal energy access', Energy for Sustainable Development,. Vol. 52, pp.128-146 [online] https://doi.org/10.1016/ j.esd.2019.07.009.

Nandakumar, A.K., Beswick, J., Thomas, C.P., Wallack, S.S. and Kress, D. (2009) 'Pathways of health technology diffusion: the United States and low-income countries', Health Affairs, Vol. 28 [online] https://doi.org/10.1377/hlthaff.28.4.986.

NFRE (2016) Catalogue of Small Wind Turbines, 8th ed., Nordic Folkcentre for Renewable Energy, Hurup, Denmark.

Ockwell, D. and Byrne, R. (2015) 'Improving technology transfer through national systems of innovation: climate relevant innovation-system builders (CRIBs)', Climate Policy, pp.1-19 [online] https://doi.org/10.1080/14693062.2015.1052958.

Ockwell, D. and Mallett, A. (2013) 'Low carbon innovation and technology transfer', in Urban, F. and Nordensvärd, J. (Eds.): Low Carbon Development: Key Issues, pp.109-128, Earthscan, Routledge, Abingdon.

Ockwell, D.G., Haum, R., Mallett, A. and Watson, J. (2010) 'Intellectual property rights and low carbon technology transfer: conflicting discourses of diffusion and development', Global Environmental Change, Vol. 20 [online] https://doi.org/10.1016/j.gloenvcha.2010.04.009.

Rao, K.U. and Kishore, V.V.N. (2010) 'A review of technology diffusion models with special reference to renewable energy technologies', Renewable and Sustainable Energy Reviews, Vol. 14 [online] https://doi.org/10.1016/j.rser.2009.11.007.

Schmitz, H. and Knorringa, P. (2012) 'Learning from global buyers', The Journal of Development Studies, Vol. 37, No. 2 [online] https://doi.org/10.1080/713600073.

Szabó, S., Bódis, K., Huld, T. and Moner-Girona, M. (2013) 'Sustainable energy planning: leapfrogging the energy poverty gap in Africa', Renewable and Sustainable Energy Reviews, Vol. 28, pp.500-509 [online] https://doi.org/10.1016/j.rser.2013.08.044.

Wandera, F.H. (2020) 'The innovation system for diffusion of small wind in Kenya: strong, weak or absent? A technological innovation system analysis', African Journal of Science, Technology, Innovation and Development, pp.1-13 [online] https://doi.org/10.1080/ 20421338.2020 .1771979$.

Wandera, F.H. (2021) The Role of Technological Innovation Systems and Firm Capabilities in Diffusing SWT in Kenya: Barriers and Opportunities, Forthcoming, Moi University.

World Bank (2018) Tracking SDG7: The Energy Progress Report [online] https://www.irena.org//media/Files/IRENA/Agency/Publication/2018/May/SDG7_Tracking_report_executive_summ ary_2018.pdf (accessed 21 January 2021). 


\section{Notes}

1 In this article and in the survey on which it is based, we use the World Bank classifications of 'developing country markets' and 'high income country markets' respectively. Developing country markets cover both low, lower-middle and higher-middle income countries. Both India and China are included in this group although they possess considerable technological know-how on small wind technology and in that sense differ from most other developing country markets. They also have, however, considerable low-income populations and internal markets for renewable energy technologies, including small wind.

2 Roughly 1 billion (13\% of the world's population) live without electricity and about 3 million people (roughly $40 \%$ of the world's population) do not have access to clean fuels and technologies for cooking (WB, 2018). Associated problems include an estimated 4 million deaths per year due to household air pollution. 16 out of the top-20 access deficit countries are located in Africa [World Bank, (2018), p.3].

3 For a thorough discussion of all the challenges related to small wind, see Wandera (2020).

\section{Appendix}

\section{Elaboration of methodology and numerical data for spider diagrams}

The responding firms reported export activities to the following developing countries (numbers in brackets refer to reported instances of exporting): Afghanistan (3), Bangladesh (1), Belarus (1), Belize (2), Bosnia and Herzegovina (1), Brazil (2), China (2), Colombia (1), Egypt, Arab Rep. (1), Ethiopia (3), Ghana (1), Guatemala (1), Haiti (2), India (4), Indonesia (1), Jamaica (1), Kenya (2), Madagascar (1), Malawi (1), Malaysia (1), Maldives (1), Marshall Islands (1), Mongolia (1), Morocco (1), Mozambique (1), Myanmar (1), Namibia (1), Nepal (1), Nicaragua (1), Pakistan (1), Papua New Guinea (2), Peru (1), Solomon Islands (1), Somalia (1), South Africa (1), Sri Lanka (1), Suriname (1), Tanzania (1), Thailand (1), Tunisia (1), Turkey (3), Uganda (1), Ukraine (1) and Vietnam (2).

Table A1 Key sections of the survey, key issues and data points

\begin{tabular}{lll}
\hline Key sections of the survey & \multicolumn{1}{c}{ Dimensions/indicators } & Measurement scale \\
\hline Exports & - Exports as a percentage of total sales last & Small increase \\
& five years in low- and high-income & Big increase \\
& markets & No change \\
& - Evolution of exports in the next five years & Big/small decrease \\
& in low- and high-income markets & $1=$ basic \\
$\begin{array}{l}\text { Rating of capabilities of } \\
\text { buyers in developing } \\
\text { country markets and } \\
\text { high-income markets }\end{array}$ & - Kreparing feasibility reports & $2=$ pre-intermediate \\
& - Selecting project sites & $3=$ intermediate \\
& - Technical skills & $4=$ pre-advanced \\
& - Knowledge of small wind technology & $5=$ advanced \\
& - Handling of import procedures for small & \\
& wind technologies & \\
& - Project management & \\
\hline
\end{tabular}


Table A1 Key sections of the survey, key issues and data points (continued)

\begin{tabular}{|c|c|c|}
\hline Key sections of the survey & Dimensions/indicators & Measurement scale \\
\hline $\begin{array}{l}\text { Country conditions for } \\
\text { small wind adoption in } \\
\text { developing country } \\
\text { markets and high income } \\
\text { markets }\end{array}$ & $\begin{array}{l}\text { - Availability of: lean procedures for } \\
\text { importing to the country; skilled } \\
\text { manpower for small wind; financial } \\
\text { support for small wind; supporting firms } \\
\text { (installation, operation and maintenance); } \\
\text { support from government (FiT, subsidies, } \\
\text { etc.) }\end{array}$ & $\begin{array}{l}1=\text { basic } \\
2=\text { pre-intermediate } \\
3=\text { intermediate } \\
4=\text { pre-advanced } \\
5=\text { advanced }\end{array}$ \\
\hline $\begin{array}{l}\text { Sources of information } \\
\text { on developing country } \\
\text { markets }\end{array}$ & $\begin{array}{l}\text { - Trade fairs } \\
\text { - Internet } \\
\text { - Pone contact } \\
\text { - Mail contact } \\
\text { - Consultancies } \\
\text { - Intermediaries } \\
\text { - Other }\end{array}$ & $\begin{array}{l}\text { Absent } \\
\text { Present }\end{array}$ \\
\hline Support to buyers & $\begin{array}{l}\text { - Conducting feasibility studies } \\
\text { - Joint project solving } \\
\text { - Operation and maintenance services } \\
\text { - Knowledge on SWT products } \\
\text { - Access to financing options } \\
\text { - Technical } \\
\text { - Assistance on installation }\end{array}$ & $\begin{array}{l}\text { Absent } \\
\text { Present }\end{array}$ \\
\hline Joint project development & $\begin{array}{l}\text { - Prior experience in joint project } \\
\text { development }\end{array}$ & $\begin{array}{l}\text { Absent } \\
\text { Present }\end{array}$ \\
\hline $\begin{array}{l}\text { Reasons for not exporting } \\
\text { to low income markets/ } \\
\text { how to improve } \\
\text { conditions in low income } \\
\text { markets/other comments }\end{array}$ & $\begin{array}{l}\text { - Opportunities } \\
\text { - Barriers } \\
\text { - Measures for diffusing small wind } \\
\text { technology in developing country markets }\end{array}$ & N/A \\
\hline
\end{tabular}

Source: Authors' own data

Table A2 Respondents' assessment of the conditions for small wind technology adoption in the markets to which suppliers export - country level capabilities

\begin{tabular}{lccc}
\hline & $\begin{array}{c}\text { Developing } \\
\text { countries }\end{array}$ & $\begin{array}{c}\text { High income } \\
\text { countries }\end{array}$ & Difference \\
\hline Availability of financial support for small wind & 1.61 & 2.62 & 1.01 \\
Availability of skilled manpower for small wind & 1.74 & 2.92 & 1.18 \\
Knowledge of small wind & 1.85 & 3.00 & 1.15 \\
Availability of supporting firms & 2.03 & 3.05 & 1.02 \\
Availability of lean procedures for importing & 2.03 & 3.11 & 1.08 \\
\hline
\end{tabular}

Source: Authors' own data 
Table A3 Respondents' assessment of the conditions for small wind technology adoption in the markets to which suppliers export - firm level capabilities

\begin{tabular}{lccc}
\hline & $\begin{array}{c}\text { Developing } \\
\text { countries }\end{array}$ & $\begin{array}{c}\text { High income } \\
\text { countries }\end{array}$ & Difference \\
\hline Preparing feasibility reports & 1.61 & 2.58 & 0.98 \\
Selecting project sites & 1.76 & 2.64 & 0.88 \\
Knowledge of small wind technologies & 1.85 & 2.92 & 1.07 \\
Knowledge regarding access to financing & 1.97 & 3.00 & 1.03 \\
Project management & 2.06 & 3.28 & 1.22 \\
Technical skills & 2.15 & 3.19 & 1.04 \\
Handling of import procedures for small wind & 2.27 & 2.75 & 0.48 \\
\hline
\end{tabular}

Source: Authors' own data

Firm capabilities in high- and low-income countries were assessed based on the following measures: technical skills; project management; knowledge regarding access to financing; knowledge of small wind technology; handling import procedures for small wind technology; preparing feasibility reports; and selecting project sites. Country-level capabilities were assessed based on these measures: lean procedures for import; the availability of skilled manpower and financial support; the nature of support given to firms for operation and maintenance; and government FiT/subsidies.

Respondents were requested to rate the firm and country-level capabilities on a scale of 1-5 where: $[1=$ basic (lowest); 2 = pre-intermediate; 3 = intermediate; $4=$ pre-advanced; and $5=$ advanced (highest)]. The opportunities, barriers and measures for diffusing small wind in developing country markets were also assessed. A summary of the key sections of the survey, key issues and data points is presented in Table A1. 